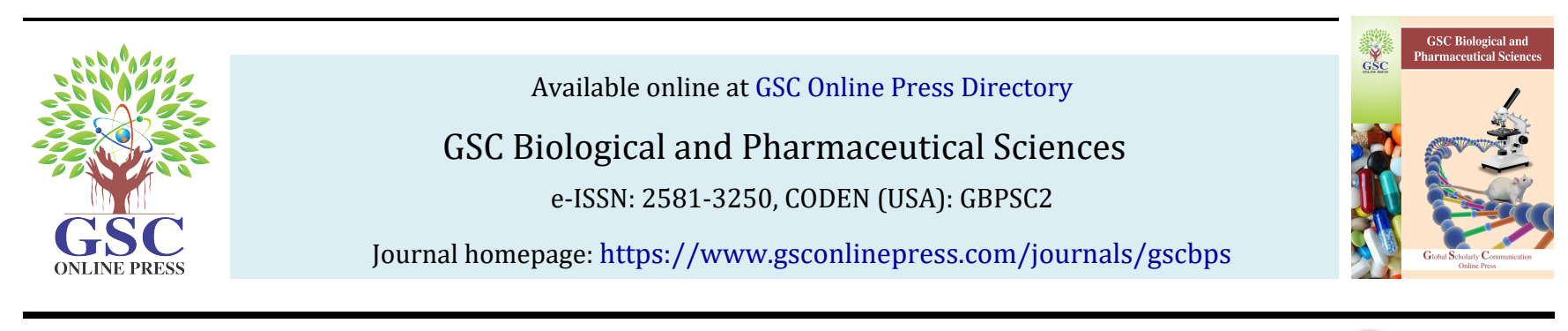

(RESEARCH ARTICLE)

\title{
Effect of plant oil treatments against Sitophilus zeamais Motsch. (Coleoptera: Curculionidae) on stored maize
}

\begin{abstract}
Wahedi Jasini Alexander 1*, Elkanah Obadiah Sambo 2, Danba Elizabeth Pius 2, Zakariya Rebecca 3, Ishuwa Miriam Nguuma ${ }^{4}$, Vincent Victor Miyananiyi ${ }^{1}$ and Wilson Chabiya ${ }^{1}$
\end{abstract}

${ }^{1}$ Department of Zoology, Adamawa State University Mubi, Nigeria.

2 Department of Biological Sciences, Taraba State University Jalingo, Nigeria

${ }^{3}$ Department of Botany, Ahmadu Bello University, Zaria, Nigeria.

${ }^{4}$ Department of Biological Sciences, University of Mkar, Gboko, Nigeria

Publication history: Received on 27 August 2017; revised on 19 September 2017; accepted on 06 November 2017

https://doi.org/10.30574/gscbps.2017.1.2.0007

\begin{abstract}
The effect of plant oil treatments extracted from Khaya ivorensis and Azadirachta indica was evaluated on adult maize weevils Sitophilus zeamais reared on maize grain. Four replicates of each treatment oils were constituted at $0 \%$ (control untreated), $1 \mathrm{ml}, 2 \mathrm{ml}$, and $3 \mathrm{ml}$ doses. Each of the pytochemical oil and the synthetic chemical (DakshDichlorvos 100\% EC w/v) was introduced into experimental jars $\left(300 \mathrm{~cm}^{3}\right)$ at graded levels, before $20 \mathrm{~g}$ of clean maize grain was incorporated. The treatment oils were separated from the grains with perforated white paper, before 10 newly emerged adult $S$. zeamais was added to the experimental jars including the control (untreated) experiment, which contain $20 \mathrm{~g}$ of maize grain but no treatment was added. The plant oils were evaluated for their toxic effect on $S$. zeamais, oviposition, F1 progeny emergence, grain damage and weight loss. Data collected were analyzed using ANOVA. The means were separated using LSD at P $>0.05$. The results revealed that treatment oils were toxic to the maize weevils when compared with the control (untreated) experiment. Among the plants, essential oil of K. ivorensis significantly $(\mathrm{P}>0.05)$ suppressed egg laying, F1 progeny emergence and grain damage. Therefore, the essential oil of $K$. ivorensis and $A$. indica is useful in the control of $S$. zeamais.
\end{abstract}

Keywords: Azadirachta indica; Khaya ivorensis; Maize; Plant oil; Sitophilus zeamais

\section{Introduction}

The storage of maize grains by the farmers is necessary from one harvest to the next in order to maintain the constancy of supply throughout the year and also to preserve its quality until required for use. In sub-tropical Africa, small scale farmers store maize for the purpose of ensuring household food supply and seeds for planting [1]. But unfortunately, the infestation of the grains by the maize weevils aggravates shortage of supply both in quality and quantity, particularly in the sub-tropic and tropic regions of Africa. Postharvest loss of maize grains between $20 \%$ and $30 \%$ has been reported [2]. Worldwide, about $66 \%$ of maize is used for feeding livestock, $25 \%$ for human consumption and $9 \%$ for industrial purposes [3]. In the developing world, about $50 \%$ of all maize is consumed as food while $43 \%$ is used for feeding of livestock and $7 \%$ for industrial purposes [3]. In Nigeria, about 50-70\% constitutes livestock feeds [4].

Maize is an important source of carbohydrate in the tropics and is a major staple in Nigeria for large human populations, important feed for poultry and also used for industrial purposes [1]. It is also rich in protein [5]. Despite

\footnotetext{
${ }^{*}$ Corresponding author

E-mail address: wahedijasini@gmail.com
}

Copyright (C) 2017 Author(s) retain the copyright of this article. This article is published under the terms of the Creative Commons Attribution Liscense 4.0. 
its importance, the production of maize suffers great losses in storage due to insect pest infestation, which necessitates farmers and researchers all over the world to find an alternative storage measures. The pest affecting maize includes Sitophilus zeamais Motschulski [6]. Generally the storage control of insect like S. zeamais has involved mainly the use of synthetic insecticides. Even though, synthetic chemicals continue to play an important role in reducing storage losses due to insect pest activities [7], but insecticide resistance [8], toxic residues in food and environmental pollution, adverse effects on beneficial and non-target insects, increased risk of workers safety and the high cost of chemical insecticides make them less attractive [7, 9]. These problems have necessitated the search for alternatively eco-friendly insect pest control method among, which are the use of plant oils. Plant derived materials are more readily biodegradable. Farmers can easily and cheaply produce these plant materials for their use.

Many plant oils have been employed for the control of post-harvest losses due to insect pest activities with varying degrees of success $[10,11]$. Many plant essential oils show different activities against controlling pest. The oils also have long tradition of use in controlling and protecting stored products. Research showed that some chemical constituents of these oils interfere with the Octapaminergic nervous system in insects [12]. Shaaya et al. reported that edible oils are potential control agents against $S$. zeamais and can play an important role in stored grain production [13]. Koul et al. also observed that the oils of neem and mahogany oil acted as surface protectant on green gram to check the impulse beetles and among them, neem oil was found to be the best surface protectant [12]. In this study, the efficacy of plaint oils extracted from $K$. ivorensis and A. indica was evaluated on $S$. zeamais reared on maize grains in Mubi.

\section{Material and methods}

\subsection{Study Area}

This experiment was carried out in the Laboratory of Biological Sciences, Adamawa State University Mubi. Mubi is a town in Adamawa State, Nigeria located on latitude $10^{\circ} 12^{\prime} \mathrm{N}$ and longitude $13^{\circ} 10^{\prime} \mathrm{E}$. It is characterized with two seasons i.e. dry and rainy seasons. The average annual rainfall ranges from $700 \mathrm{~mm}$ to $1050 \mathrm{~mm}$. The average minimum temperature is $15.2^{\circ} \mathrm{C}$ in the month of December and January, with maximum temperature of $42{ }^{\circ} \mathrm{C}$ [14].

\subsection{Sources of plant oil treatments and synthetic chemical}

The plant oil treatments used in this study was sourced from the seeds of Azadirachta indica and Khaya ivorensis. These were obtained freshly from a plantation in Fadama Rake, Hong, Adamawa State. The seeds were dried in a dark cupboard and were subsequently shelled and pulverized into fine powders using electric blender. For each plant powder, the oil was extracted as described by Wahedi et al. [15], as follows: Boiled water was added gently on the plant powder in a wider container and was moulded to form a dough-like substance. This was continually pressed on a clean wood plant until the oils are out. The oil was collected and stored in a dark bottle with tight lids. Synthetic chemical Daksh (Dichlorvos 100\% EC w/v) was obtained from agrochemical store in Mubi main market, and was used as the positive control.

\subsection{Maize grain}

Clean maize grain was obtained from a farmer in Fadama Rake in Hong LGA and was dried to a constant weight in an oven between $30^{\circ} \mathrm{C}$ and $35^{\circ} \mathrm{C}$ for 5 days. It was subsequently air-dried for about 30 minutes and was wrapped tightly in a container.

\subsection{Insect culture}

Initial stock (parent stock) of maize weevils Sitophilus zeamais was obtained from already infested maize grains in a storage room in Mubi main market. The insects were thereafter exposed to a clean maize grain in about $500 \mathrm{~cm}^{3}$ culture jar. They were subsequently discarded after 3days, and the infested grains were maintained under laboratory conditions for adult $S$. zeamais emergence. This helped in raising adult $S$. zeamais of uniform size and age.

\subsection{Method of application}

Each of the treatment was constituted as follows: $1 \mathrm{ml}, 2 \mathrm{ml}$, and $3 \mathrm{ml}$. The treatments were first introduced into the rearing jars using a calibrated syringe. The treatments were thereafter covered with perforated paper to prevent a direct contact of the weevils with the oil treatments. $20 \mathrm{~g}$ of maize each was added to the rearing jars before the introduction of the experimental insects. 10 newly emerged adult $S$. zeamais were introduced into the rearing jars and were covered with muslin cloth using rubber band in order to prevent the insects from escaping and to allow entry of 
oxygen. The control jar, also contain 20 g of maize grains and 10 newly emerged adult weevils but no treatment in it was constituted.

\subsection{Data collection}

\subsubsection{Mortality}

Mortality count of adult S. zeamais was noted and recorded for four days post treatment. This was done by emptying the content of the rearing jars on a clean silver tray and noting the number of death insects. The inability of the insect to respond to a touch using a broom stick indicated mortality. Thereafter, the content of the jars were subsequently put back after the death insects have been retrieved.

\subsubsection{Oviposition}

The number of eggs per jar was determined using the acid fuschin staining method. Ten maize grains from each jar were randomly selected on the $12^{\text {th }}$ day post treatment, soaked in warm water for 2-3 minutes, drained and subsequently immersed in $0.5 \%$ acid Fuschin for about 2-5 minutes. The grains were rinsed in water and examined for the red gelatinous egg plugs. The number of egg plugs noticed on the ten grains was then extrapolated for the entire jar using an average number of 96 maize grains per jar [16].

\subsubsection{F1 generation:}

The number of F1 adult progeny of S. zeamais that emerged per jar was noted and recorded between 7-8 weeks of setting up the experiment.

\subsubsection{Grain damage}

The number of grain damaged was noted by counting the number of punctures and holes on the grains. 10 seeds were randomly selected from each treatment jar and were noted for the damage. The numbers of damages recorded were extrapolated using an average number of seeds (96) per jar as described in oviposition above.

\subsubsection{Weight loss}

Weight loss by the maize grain per jar was calculated as the difference between the initial weight and the final weight of the grains as shown in the formula below.

Weight loss = final weight - initial weight.

\subsection{Data analysis}

Data collected was subjected to Analysis of Variance (ANOVA) using statistical analysis software (SAS) at $5 \%$ (P $>0.05$ ) level of significance, while the mean differences were separated using Least Significant Difference (LSD).

\section{Results}

\subsection{Mortality}

Table 1 Effect different oil treatments on the mortality of adult Sitophilus zeamais reared on maize grain

\begin{tabular}{|c|c|c|c|c|c|}
\hline \multirow[t]{2}{*}{ Treatment } & \multirow[t]{2}{*}{ Dose (ml) } & \multicolumn{4}{|c|}{ Days (Mean \pm SD) } \\
\hline & & 1 & 2 & 3 & 4 \\
\hline Control & 0.0 & $0.00 \pm 0.00^{a}$ & $0.00 \pm 0.00^{a}$ & $0.00 \pm 0.00^{a}$ & $0.00 \pm 0.00^{a}$ \\
\hline \multirow[t]{3}{*}{ Khaya ivorensis } & 1.0 & $0.50 \pm 1.00^{\mathrm{a}}$ & $1.50 \pm 0.58^{b}$ & $3.00 \pm 0.82^{b}$ & $4.50 \pm 2.38^{b}$ \\
\hline & 2.0 & $1.25 \pm 1.25^{\mathrm{ab}}$ & $2.25 \pm .50^{\mathrm{bc}}$ & $4.25 \pm 0.71^{b}$ & $2.25 \pm 1.71^{\mathrm{ab}}$ \\
\hline & 3.0 & $2.75 \pm 1.25^{b}$ & $3.00 \pm 0.81^{c}$ & $2.75 \pm 1.50^{b}$ & $1.00 \pm 1.41^{\mathrm{a}}$ \\
\hline Azadirachta & 1.0 & $1.25 \pm 1.25^{b}$ & $2.25 \pm 0.96^{b}$ & $2.50 \pm 1.00^{\mathrm{b}}$ & $4.00 \pm 2.16^{b}$ \\
\hline \multirow[t]{2}{*}{ indica } & 2.0 & $1.75 \pm 1.26^{b}$ & $2.75 \pm 0.96^{b}$ & $2.75 \pm 1.50^{b}$ & $2.75 \pm 1.71^{b c}$ \\
\hline & 3.0 & $4.00 \pm 1.00^{c}$ & $3.00 \pm 0.82^{b}$ & $2.25 \pm 0.82^{b}$ & $1.00 \pm 0.82^{\mathrm{ab}}$ \\
\hline \multirow[t]{3}{*}{ Daksh } & 1.0 & $4.75 \pm 1.26^{b}$ & $2.25 \pm 0.50^{\mathrm{b}}$ & $2.00 \pm 0.81^{b}$ & $1.00 \pm 0.82^{\mathrm{ab}}$ \\
\hline & 2.0 & $5.50 \pm 0.56^{b c}$ & $1.25 \pm 0.50^{\mathrm{ab}}$ & $2.25 \pm 0.50^{\mathrm{b}}$ & $1.00 \pm 0.82^{\mathrm{ab}}$ \\
\hline & 3.0 & $6.50 \pm 1.29^{c}$ & $1.00 \pm 1.41^{\mathrm{ab}}$ & $0.50 \pm 0.56^{\mathrm{a}}$ & $0.75 \pm 0.95^{b}$ \\
\hline
\end{tabular}


Table 1 shows the toxicity effect of treatments (K. ivorensis and A. indica) on adult Sitophilus zeamais on stored maize. Although the mortality was spread across the four days of exposure, there was significant differences $(P>0.05)$ in the mortality recorded per treatment across the period of exposure. No mortality (0.00) was recorded in the control (untreated) experiment throughout the four days. The overall results on mortality revealed that the treatment oils were quick active as they recorded a significant $(\mathrm{P}>0.05)$ number of mortality in all the treatments after 24 hrs of exposure.

\subsection{Oviposition, F1 generation emergence, grain damage and grain weight loss}

The effect of the phytochemical oils in the suppression of adult $S$. zeamais from egg laying and F1 emergence as well as the protection of maize grain from damage and subsequent weight loss is shown in Table 2 . Although the phytochemicals could not stop the adult weevils $S$. zeamais from laying eggs completely, there was a significant difference $(\mathrm{P}>0.05)$ in the number of eggs laid as well as the F1 progeny emergence, when compared with the control (untreated) experiment. The number of eggs laid as well as the number of F1 adults emerged do not differ significantly $(\mathrm{P}>0.05)$ per treatment at different doses. No F1 adult $(0.00 \pm 0.00)$ emergence was recorded on maize grain treated with $K$. ivorensis in all the treatment doses $(1.0 \mathrm{ml}, 2.0 \mathrm{ml}$ and $3.0 \mathrm{ml})$ as well as A. indica at $3.0 \mathrm{ml}$ treatment dose respectively.

The result also revealed that there was a significant difference $(\mathrm{P}>0.05)$ in the number of grain damage and subsequent weight loss by the maize grain compared with the control (untreated) experiment. The control experiment significantly ( $\mathrm{P}>0.05)$ recorded higher grain damage $(42.00)$ as well as the weight loss $(2.00)$. Among the phytochemical oils, no significance difference $(\mathrm{P}>0.05)$ was observed at all doses.

Table 2 Effects of treatments on oviposition, F1 adult emergence of Sitophilus zeamais and maize grain damage and weight loss

\begin{tabular}{|c|c|c|c|c|c|}
\hline \multirow[t]{2}{*}{ Treatment } & \multirow[t]{2}{*}{ Dose (ml) } & \multicolumn{4}{|c|}{ Parameters (Mean \pm SD) } \\
\hline & & Oviposition & F1 emergence & Grain damage & Weight loss (g) \\
\hline Control & 0.0 & $51.85 \pm 17.73^{b}$ & $4.25 \pm 0.95^{b}$ & $42.00 \pm 5.43^{b}$ & $2.00 \pm 0.71^{b}$ \\
\hline \multirow[t]{3}{*}{ Khaya ivorensis } & 1.0 & $16.45 \pm 14.10^{\mathrm{a}}$ & $0.00 \pm 0.00^{\mathrm{a}}$ & $7.05 \pm 4.70^{\mathrm{a}}$ & $1.15 \pm 0.07^{\mathrm{a}}$ \\
\hline & 2.0 & $9.40 \pm 7.67 \mathrm{a}$ & $0.00 \pm .00^{\mathrm{a}}$ & $0.00 \pm 0.00^{\mathrm{a}}$ & $0.82 \pm 0.33^{a}$ \\
\hline & 3.0 & $18.8 \pm 7.67^{a}$ & $0.00 \pm 0.00^{\mathrm{a}}$ & $4.70 \pm 5.42^{\mathrm{a}}$ & $0.72 \pm 0.00^{\mathrm{a}}$ \\
\hline \multirow{3}{*}{$\begin{array}{l}\text { Azadirachta } \\
\text { indica }\end{array}$} & 1.0 & $25.85 \pm 16.05^{\mathrm{a}}$ & $0.25 \pm 0.50^{\mathrm{a}}$ & $4.70 \pm 5.42^{\mathrm{a}}$ & $1.20 \pm 0.24^{\mathrm{a}}$ \\
\hline & 2.0 & $23.50 \pm 12.13^{a}$ & $0.25 \pm 0.50^{\mathrm{a}}$ & $2.35 \pm 4.70^{\mathrm{a}}$ & $1.07 \pm 0.22^{\mathrm{a}}$ \\
\hline & 3.0 & $23.65 \pm 19.61^{a}$ & $0.00 \pm 0.00^{\mathrm{a}}$ & $2.35 \pm 4.70^{\mathrm{a}}$ & $0.77 \pm 0.15^{\mathrm{a}}$ \\
\hline \multirow[t]{3}{*}{ Daksh } & 1.0 & $40.10 \pm 8.73^{\mathrm{a}}$ & $1.00 \pm 0.00^{\mathrm{a}}$ & $16.45 \pm 14.10^{\mathrm{a}}$ & $0.97 \pm 0.35^{\mathrm{a}}$ \\
\hline & 2.0 & $39.95 \pm 16.05^{a}$ & $0.75 \pm 0.50^{\mathrm{a}}$ & $11.75 \pm 17.79^{a}$ & $0.55 \pm 0.23^{a}$ \\
\hline & 3.0 & $35.25 \pm 11.82^{\mathrm{a}}$ & $0.00 \pm 0.00^{\mathrm{a}}$ & $11.75 \pm 17.79^{a}$ & $0.50 \pm 0.21^{\mathrm{a}}$ \\
\hline
\end{tabular}

\section{Discussion}

The oils tested were found to be effective in the control of adult S. zeamais on stored maize. A. indica and K. ivorensis gave $100 \%$ mortality in all the treatment doses used $(1.0 \mathrm{ml}, 2.0 \mathrm{ml}$ and $3.0 \mathrm{ml})$ after 4 days of exposure, equal to the synthetic insecticides. This confirms the efficacy of the oil treatments used; thus could be a suitable replacement for the insecticides which are toxic to its users and the environment, relatively not affordable to local farmers, as well as its effect on non-target organisms. The plant oils were quick in action as they recorded significant $(\mathrm{P}>0.05)$ mortality after 24 hrs of exposure. The treatment doses showed no significant difference $(\mathrm{P}>0.05)$ in the number of adult mortality, but performed significantly $(\mathrm{P}>0.05)$ better when compared with the control (untreated) experiment. The results achieved in this study agrees with the work reported by Wahedi among previous studies, who reported that $A$. indica significantly caused high mortality of $S$. zeamais reared on stored maize; and that the toxicity of the treatment was associated with the occurrence of chemical components such as tritepenoids, which comprise azadirachtin [17]. 
The significant number of adult mortality recorded and a significant $(\mathrm{P}>0.05)$ suppression of adult emergence of $S$. zeamais by the plant oil treatments suggests that the seeds are have toxic compounds that have insecticidal properties [18]. The oil on application on the grain serve as food poison to the weevils, the odour penetrated into the endosperm and germ layer thereby preventing oviposition and larval development as reported by Arannilewa et al. [18].

The observed low emergence of F1 generation of $S$. zeamais on maize grains treated with two plants oils could be as a result of a significant $(\mathrm{P}>0.05)$ high mortality earlier recorded on adult $S$. zeamais, thus affected their mating process and sexual communication as well as deterring females from lying eggs; and hence, a complete suppression of the developmental stages of the insects. The trial has showed that treating maize grain with $A$. indica and $K$. ivorensis oil at all treatment doses, prevented adult $S$. zeamais emergence, suppressed weight loss and grain damage caused by $\mathrm{S}$. zeamais activities. This also coincides with the findings of Wahedi [17] and Yusuf et al. [19], who reported a reduction in weight loss of maize grains treated with neem seed oil.

\section{Conclusion}

In conclusion, the plant oil treatments extracted from $A$. indica and $K$. ivorensis no doubt hold some promising effects in respect of the control of stored grains against insect pest infestation. More so, the fact that they are readily available and environmentally friendly put them in a stead of tapping as an alternative to the chemical pesticides, which are toxic to humans.

\section{Compliance with ethical standards}

\section{Acknowledgments}

The authors wish to acknowledge the contributions of Mr. Ibrahim Bayaso of Adamawa State Ministry of Agriculture, Yola, for performing the statistical analysis, and interpreting the results.

\section{Disclosure of conflict of interest}

This work was collaboratively carried out between all authors as follows: Author Wahedi JA, designed and supervised the study, wrote the protocol, and wrote the first draft of the manuscript; Author Zakariya R, identified and performed the extraction plant treatment oils; Authors Wilson C, and Vincent VM, performed the experiment; Authors Elkanah OS, Danba EP, and Ishuwa MN, managed the literature searches. All authors read and approved the final manuscript.

\section{References}

[1] FAO (2007). http://www.fao.org/inpho/maize (Internet Information, Accessed)

[2] Gwinner J, Harnisch R and Műck O. (1990). Manual on the prevention of post-harvest grain losses, post-harvest project, Pickhuben 4, D-2000 Hambung.

[3] IITA (2003). Research Guide 30, IITA Training program PNB 5320, Ibadan, Nigeria, 43.

[4] Agoda S, Atanda S, Usanga OE, Ikotun I and Isong IU. (2011). Post-harvest food losses reduction in maize production in Nigeria. African Journal of Agricultural Research, 6(21), 4833-4839.

[5] Dasbak MA, Echezona BC and Asiegbu JE. (2008). Post-harvest richness and residual activities of pirimiphos methyl on Callosobruchus maculatus F. infested Pigeon pea (Cajanus cajan L. Mill sp) in storage. African Journal of Biotechnology, 8 (2), 311-315.

[6] Longstaff BC. (1981). Biology of the grain pest species of the genus Sitophilus (Coleoptera: Curculionidea): A critical review protection Ecology, 2, 83-130.

[7] Niber BT. (1994). The ability of powders and slurries from ten plants species to protect stored grain from attack by Prostephanus truncates Horn. (Coleoptera: Bostrichhidea) and Sitophilus oryzae L. (Coleoptera: Curculionidea). Journal of Stored Product Research, 30, 297-301.

[8] Perez-Mendoza J. (1999). Survey of insecticide resistance in Mexican population of maize weevil, Sitophilus zeamais Motschuski (Coleoptera: Curculionidae). Journal of Stored Product Research, 36 (1): 107-115. 
[9] Asawalam EF, Emosairue SO and Hassanali A. (2006). Constituents of the Essential oil of Vernonia amygdaline as maize weevil protection. Tropical and subtropical Agroecosystems Facultad de medicina Veterinaria Zootecina, Universitad Autonoma de yucatan, Mexico, 6(2), 95-102.

[10] Schmutterer H. (2002). The neem tree: source of unique national products for integrated pest management. Medicine, Industry and Other Purposes. ISBN, 3, 527-30054.

[11] Koul 0. (2008). Phytochemicals and insect control: An antifeedant approach, Critical Reviews in Plant Sciences, 27, 1-24.

[12] Koul 0, Wallia S, and Dhaliwal GS. (2008). Essential oils as green pesticides: Potential and constraints. Biopesticide International, 4(1), 63-84.

[13] Shaaya E, Kostjukovski M, Eilberg J and Sukprakan C. (1997). Plant oils as fumigants and contact insecticides for the control of stored products insects. Journal of Stored Product Research, 33 (1), 7-15.

[14] Adebayo A and Tukur AL. (1999). Adamawa State in Maps, Paraclete Publisher, Yola, 27-31.

[15] Wahedi JA, David LD, Edward A, Mshelmbula BP and Bullus Z. (2013). Efficacy of seed powder and extracts of Azadirachta indica Linn (Meliaceae) at graded levels on adult Callosobruchus maculatus (Coleoptera: Bruchidae) in Mubi, North-eastern Nigeria. International Journal of Science and Nature, 4 (1), 138-141.

[16] Wahedi JA, Ande AT and Fatoba PO. (2013). Biocidal activities of some tropical moss powders against Sitophilus zeamais Motch (Coleoptera: Curculionidae). Global Journal of Bio-Science and Biotechnology, 2 (3), $386-389$.

[17] Wahedi JA. (2012). Laboratory evaluation of neem (Azadirachta indica Linn (Meliaceae)) seed powder and seed oil for the control of Sitophilus zeamais (Coleoptera: Curculionidea) on stored maize. Adamawa State University Journal of Scientific Research, 2(2), 110-115.

[18] Arannilewa ST., Ekrakene T and Akinneye JO. (2006). Laboratory Evaluation of four medical plants as protectants against the maize weevil, Sitophilus zeamais (Motschulski). Africa Journal of Biotechnology, 5(21), 2032-2036.

[19] Yusuf SR, Ahmed BI, Chaudhary IP and Yusuf AU. (1998). Laboratory evaluation of maize weevil (Sitophilus zeamais) in stored maize. Entomological Society of Nigeria, 31, 203-213.

\section{How to cite this article}

Wahedi JA, Elkanah OS, Danba EP, Zakariya R, Ishuwa MN, Vincent VM and Wilson C. (2017). Effect of plant oil treatments against Sitophilus zeamais Motsch. (Coleoptera: Curculionidae) on stored maize. GSC Biological and Pharmaceutical Sciences, 1(2), 01-06. 